\title{
The History of Islam in St Petersburg*
}

\author{
ANAS B. KHALIDOV
}

Islam in St Petersburg, strange as it may seem to some, goes back to the very foundation of the city. Its history is linked firstly with the local Muslim congregation and secondly with the academic, scientific and political institutions of the city as the capital of a huge state.

Muslims were among those who first arrived to build the city. ${ }^{1}$ In line with the declared will and the edicts of Peter I, manpower and resources from throughout the country were drawn in, and Muslims living in Russia at that time were no exception. They were obliged to supply workmen who were responsible for providing their own food, tools, horses and fodder. At that time, the beginning of the eighteenth century, the Muslim population of the Russian Empire consisted of Tatars whose lands had been conquered and had ceased to be a separate state in the middle of the sixteenth century. The Tatars who helped to build St Petersburg came from Kazan', Kasimov, Sergach, Nizhny Novgorod, Samara and Astrakhan' - in other words the whole Volga basin. D. Aminov quotes one of the early surviving descriptions of St Petersburg in the first half of the eighteenth century (by one Andrei Bogdanov):

On the St Petersburg side there is an enclave called Tatarskaya... from Bol'shaya Nikol'skaya to Mytny Dvor. There used to be Tatar yurts here, which is why Bol'shaya and Malaya Nikol'skaya are called the Tatar streets. This is because from the beginning of the work on building the St Petersburg earthwork fortress, the Tatars were employed to cover it with turf and then to carry out all kinds of work with the artillery.

It was not only construction workers from among the Russian Muslims who came to St Petersburg, but also merchants, artisans of various professions and people who had entered the service. The tsarist government also attracted Muslims to serve in the army and the navy, and in the lifeguards who protected the imperial family and palaces. Peter the Great and his successors waged successful wars of conquest around the Black Sea and in the Caucasus, and little by little Muslims from these regions too came to settle in St Petersburg.

The number of Muslims in St Petersburg apparently never exceeded one to one-anda-half per cent of the population; but estimates of the Muslim population, whether permanent or transient, were never very regular or reliable. According to the census of 1869 there were 2,000 Tatars in the city; but this figure did not include the guards who had quarters there or sailors of the Baltic fleet, or, apparently, the inhabitants of suburbs with a significant concentration of Tatars such as Kronshtadt and Ligovo. 
The northern capital of the Orthodox Christian empire would obviously frequently be an indifferent or hostile environment for Muslims. As a minority in an alien ethnic, religious and cultural milieu they had to think about survival and self-protection. One option for them was to embrace Christianity and to become Russian in language and culture; if they fulfilled this condition, they were permitted to enter the nobility. There are dozens of well-known Russian families of such extraction, and they have produced many outstanding figures who have contributed to the glory of Russian culture and science, such as Karamzin, Saltykov, Turgenev, Chaadayev, Derzhavin and Rerikh. In general, however, the Tatar Muslims strove to hold on to their faith, their language, their literacy, their customs and the chance to train and teach their children in accordance with their beliefs and the traditions of their ancestors. The prayer house served as their organisational centre, but the Muslims of St Petersburg did not have a purpose-built mosque until the beginning of the twentieth century. For public prayers they adapted some sort of room in an ordinary building in the places where Muslims lived close together in national groupings, or in the quarters provided by the relevant military units. Something like 'Muslim parishes' developed analogous to church parishes. In guards units and on ships which were manned chiefly, or to a significant degree, by Muslims, official posts were created for muezzins and mullahs, and in the officers' and cadets' schools provision was made for experts to teach Muslim law; there was also the senior post of 'Akhun of the Guard'.

The particular nature of Islam in St Petersburg was a consequence of the fact that this was a capital city, hub of the foreign policy activity of a huge state; it was here that diplomats were received from eastern countries, including Muslim ones, as well as from the Christian states of Europe which had colonies in the Muslim world; it was here that diplomats, colonial officials and translators were trained. The tsarist government and high society therefore had to demonstrate, as evidence of an enlightened monarchy, their tolerance, indulgence and kindness to people of other faiths and nations. It was in St Petersburg that oriental studies first developed, including as an important element the study of Islamic civilisation, and of Arabic, Persian and Turkish languages and literatures. The main academic libraries of the city - the Asiatic Museum of the Academy of Sciences, the Public and the University Libraries - started collections of manuscript and printed documents and books from the Crimea and Transcaucasia, and later from the Muslim East, including Central Asia, conquered in the second half of the nineteenth century; and also of printed works about the Muslim East in various languages. These collections gradually became the richest in Russia. The museums of the city gradually accumulated artistic, cultural and household objects from the East. A school of Islamic and Arabic studies was founded under the direction of academics of repute such as Ch. D. Frähn, V. R. Rozen, V. V. Bartol'd and I. Yu. Krachkovsky. Its approach was characterised by the desire to study the culture of the East like any other culture, objectively and without prejudice, and to form an independent judgment on the basis of verified facts. Some publishing activity also developed: the academic and university printing houses printed important works of Muslim literature, especially those that would be of use as textbooks and sources for the history of the peoples of Eastern Europe.

The presence in one city of a Muslim congregation and of oriental studies meant that there had to be mutual contacts, and even given certain distrust between the two, there was mutual benefit. From the Muslim sector came the translators, the language teachers, the library and printing press workers. The work of Husain Faizanov (1828-66) comes immediately to mind. Oriental scholars gave help and encouragement so that publishing work was established among Russian Muslims, 
especially in St Petersburg. Il'yas Mirza Boragansky from Bakhchisarai, a lecturer in Turkish language and oriental calligraphy at the Oriental Faculty of St Petersburg University from 1898-1908, received full support from the University and the Asiatic Museum to set up a private printing press in the Arabic script. Orientalists were able to use this printing press, and during the years 1901-10 it published 59 books in a total edition of 123,940 , as well as the Tatar newspaper Nur. ${ }^{2}$ His partner was the wellknown St Petersburg akhun Gataulla Bayazitov, translator and publicist. Another oriental printing press was founded in St Petersburg by Abdurashid Ibragimov in 1906; it printed a number of newspapers, including Ulfat, and a large quantity of Muslim books.

It should of course be noted that from 1874 control was exercised over the whole Russian Muslim press by the St Petersburg censor's office, which vigilantly protected Russian Muslims from any progressive, seditious ideas, and from criticisms of the government. Censorship became much stricter after 1910, and the number of Muslim books printed in the city sharply decreased.

By the beginning of the twentieth century St Petersburg was a centre of activity for Muslim business, for advocates of Muslim education and of the renewal and reform of Islam, for book publishers and publicists. It was here that Musa Bigiyev, author of The ABC of Islam (Islamiiat alifbasy) and many other books, worked for a quarter of a century. Ismail Gasprinsky, Gayaz Iskhaki and many activists from the outlying parts of Russia and abroad came and stayed here for long periods. In 1916 the charitable and educational society 'Islam va Magarif' was at work in St Petersburg. In 1910-20 the long-planned mosque was erected.

The Muslim community of St Petersburg has good reason to lament its unhappy fate during the past 74 years although, of course, it shared this fate with all Muslims in the former USSR and, perhaps, with the whole population.

During the two revolutions of 1917 and later, many Muslims were carried away by socialist and communist ideals, and took an active part in the political struggle in Russia. It may be that they gained some benefit for themselves, but on the whole there is no doubt that the Muslim nations lost a great deal, and most of the political activists were in any case later exterminated. Muslims were in the same boat as other religious communities with which they could integrate to form a unified society. They could take advantage of free education and free medicine, and consolidate into 'socialist nations' and republics, but only at the price of rejecting their traditions, their faith, language, script, most of their culture. Muslims were rarely and weakly represented in the upper echelons of the party and state nomenklatura; as a rule they were completely absent from the places where the most important decisions were taken and so they were virtually deprived of any choice or possibility of determining for themselves guidelines for their cultural, political or economic life. Under a totalitarian regime they were subject to decisions that were far from ideal, sometimes downright destructive. Muslims became second-class, persecuted communities - and, indeed, were more thoroughly persecuted than others: we should remember that most of the repressed nations were Muslim. Much is being written at the moment about judicial and extrajudicial reprisals against thousands of people, about the victims of the prisons and the camps, but it has to be said that from all this literature one could gain the false impression that repression affected everybody but Muslims. It is not impossible that someone with a deliberate bias wants to create a false impresssion. Muslims themselves have not yet been able to write great works of literature about the persecution of Muslims or carry out convincing research into the subject. All this is still to be done: there must be a 'memorial' for the Tatars and all Muslim nations. 
The composition and size of the population of Petrograd-Leningrad-St Petersburg varied enormously after 1917, and this is also true of its Muslim sector. These variations were related to such factors as the change in the city's status, the adversities of the revolutionary period and the civil war, and emigration and replenishment of the population during industrialisation, which drew people from all over the country, especially the villages. There were repeated repressions against more and more groups of people in the city in the 1920s and 1930s, and then further replenishment of the population as a result of appeals, levies, reception of students, evacuation of state and party officials and so on. The Second World War and the Siege of Leningrad again shuffled the population of the city, and after the war there were more floods of immigrants and emigrants. Muslims settled in the city as part of various incoming floods, and they also perished, emigrated and moved out at various periods. Part of the constantly renewed Muslim population of the city remained permanently, but even in the 1920s it was virtually deprived of its spiritual leaders, who were either repressed or scattered, and the Muslims were deprived of any opportunity to pray or observe their rituals. Religious persecution was scaled down in 1943, with the aim of encouraging believers to die for the triumph of the communist regime. Repressive measures had been carried out quickly, ruthlessly and secretly: the restoration of believers' rights also took place secretly, but slowly and by fits and starts. At the same time the Muslim community - like other religious groups throughout the country suffered another affliction: they were subjected to secret surveillance by the security organs, and the overwhelming majority of clergy were blackmailed and bribed into becoming informers and agents.

During the Soviet period the Muslims of St Petersburg and the rest of Russia produced a good number of well-qualified academics, doctors, cultural figures, specialists and a wide variety of professionals, who had often forgotten their past and who maintained only tenuous links with their people and vague recollections of the religion, spiritual culture and moral ideals of their ancestors. The Muslims of St Petersburg are continually subject to the corrupting influence of criminal and semicriminal circles, their lack of culture and social irresponsibility. At the same time the influence of the Muslim community has become weaker as far as education and discipline are concerned, since it is a community which has been broken up and scattered across an enormously enlarged city and has not yet recovered from waves of terror.

Nevertheless, much has been done and continues to be done towards the restoration and normal functioning of the Islamic community of St Petersburg and its cathedral mosque. A positive role has been played here by the visits of prominent politicians from eastern countries, beginning in the mid-1950s, and the opening up of the city to foreign students, visitors and businessmen.

As far as Islamic and Arabic studies are concerned, the situation is rather better. Through the efforts of the staff of the various libraries, manuscript depositories, museums and archives in St Petersburg, all the written materials and cultural items accumulated over more than two centuries were preserved - indeed, these holdings continued to increase in size almost without interruption while similar materials were being destroyed in other parts of Russia, especially in the 1930s. The continued preservation of these valuable materials will require the efforts of new generations of curators and restorers, and also considerable expense. Given the present economic situation of the city, it will be very difficult to achieve this, and the fund for the renaissance of Islam in St Petersburg can contribute its mite to this good work.

Academic research into the history and philology of the Muslim peoples has been 
carried out with no little success in recent decades in the Leningrad (St Petersburg) branch of the Institute of Oriental Studies of the Academy of Sciences. Even during the period of constant mass antireligious propaganda, this department managed to put together a team of Arabic and Islamic specialists who carried out a series of worthwhile research projects. They concentrated, it is true, mainly on the study of Islam and Arab culture outside the former USSR; now, of course, the programme of studies will have to be adjusted to concentrate on the history of Islam in Russia and the republics of Central Asia, the Caucasus and the Black Sea area. Obviously this will require the training of new staff and new sources of finance under difficult circumstances. It cannot be said that research on Islamic themes has received sufficient recognition in official circles, for example the Academy of Sciences: in contrast to the prerevolutionary period, no members of the Academy are specialising in disciplines such as Arabic studies and the history of Muslim peoples.

The renaissance of Islam in St Petersburg certainly does not imply simply reproducing what was here before. The Islamic community and Islamic studies in a metropolis like this will have to adapt to new circumstances. There are many factors hindering the renaissance of Islam in St Petersburg; I have tried to identify some and to review them briefly from a historical perspective. But there is a good chance that these negative factors can be overcome, given sufficient goodwill. Only Allah knows the future, and He will help us.

\section{Notes and References}

1 See archive materials and early printed sources in the publications of Daut Aminov. A brochure of his has just appeared, entitled Sankt-Peterburgskaya sobornaya kafedral'naya mechet': istoricheskii ocherk (IPK Impeks, St Petersburg, 1992). The author himself belongs to a Muslim Tatar family that has long been famous in the city.

2 A. G. Karimullin, Tatarskaya kniga nachala XX veka, (Kazan', 1974), 177 pp.

(Translated from the Russian by Kathy Carter) 